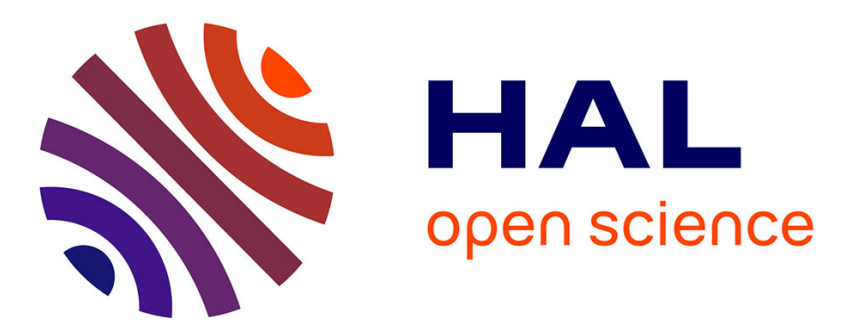

\title{
Time delay measurements in the frequency domain for indoor radio propagation
}

Gheorghe Zaharia, Ghais El Zein, Jacques Citerne

\section{To cite this version:}

Gheorghe Zaharia, Ghais El Zein, Jacques Citerne. Time delay measurements in the frequency domain for indoor radio propagation. IEEE-APS International Symposium, Chicago, 1992, Jul 1992, Chicago, United States. pp.1388-1391, 10.1109/APS.1992.221637 . hal-00875609

\section{HAL Id: hal-00875609 https://hal.science/hal-00875609}

Submitted on 5 Nov 2013

HAL is a multi-disciplinary open access archive for the deposit and dissemination of scientific research documents, whether they are published or not. The documents may come from teaching and research institutions in France or abroad, or from public or private research centers.
L'archive ouverte pluridisciplinaire HAL, est destinée au dépôt et à la diffusion de documents scientifiques de niveau recherche, publiés ou non, émanant des établissements d'enseignement et de recherche français ou étrangers, des laboratoires publics ou privés. 


\title{
TMME DELAY MEASUREMENTS IN THE FREOUENCY DOMAIN FOR INDOOR RADIO PROPAGATION
}

\author{
GHZAHARL*, G, EI ZENN and J, CITERNE \\ Laboratoife Composants et Systames pour Télbcommunications \\ URA 834, DSA, 35043 RENNES, FRANCE
}

\section{ABSTRACT}

Measurement Jesalts of average time dejay and RMS delay spread are teported. A statistic of RMS delay spread is pesented. A linear repession andysis berween the above delay dimes and the $T-R$ sepantion is also described. Using a method to discart the locotion with the maximum absolute error, this regression analysis allows us to obkin a minimum męan square tror (MMSE) Jine with more importmot correlaton coefficient and more reduced mean spuare eror.

\section{WNTAODUCTION}

Indoor radjo propagation thes been studied extensively for the evaluation of different transmission systems for appliention in portable phones and wirele is local area networks. The reported measurementa for listoor ndio chand have been performed almost exeIusively in the time dortain [1-4]. Recently, similar mearurements were performed in the frequeocy domain [5-6] using a networt andyzer.

The megsurements described in this paper were performed with a gimplified version of the setup inicially used by Fahlavan and Howard [G] and improuved by Zagloul er al. [7. It represeds the frot roport of time delay and RMS delay tpread tesults of an indoor radio chunrel measurestent campaign condueled at LCST laboratory in the Siuturese of $199 \%$.

\section{DESCRIPTION OF THE MEASIREMENTS}

The block diagran of the measumanent setwp tused for frequency dornain charocterisation of the indoor radis chamel is shown in Fis. 1 . A more detailed deseription of the measurentent setup is given in Refrence [8].

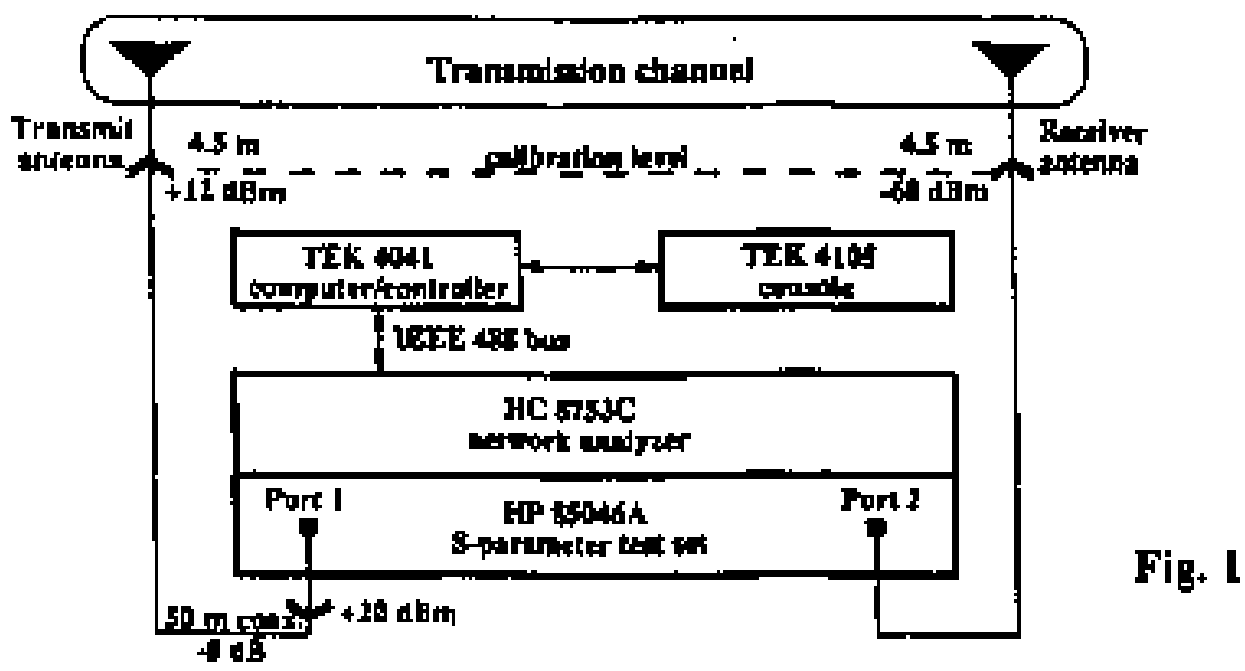

The frequency response of the channel eonsists of 801 complex smples al a frequency spacing of $0.25 \mathrm{MHz}$ for a frequeacy span of $200 \mathrm{MHz}$, which is centered at $0.9 \mathrm{MHz}$. Fom this frequency response, a time responst of 4000 ns duration is derived. The time response is truncaced to keep only that porion with significant energy. 


\section{MEASIUREMENT ANALYSIS}

The dan rate timitations for dipital trantonission systens is limited by the frequency seloctlve fadting moltipath characteristics of the channel. In the ime-dormin measmements, the darate limitations are andied by examining the statistics of the RMS delay spread [1-4]. For the frequency-domain measurements, the same anslytis may be realixed using the time-response Ih $(t, x)$ derived frotn the frequency-response $H(f, x)$ ts explained above. The RMS delay spread $\tau_{\text {Irms }}$ is comptried by $[1,6]$ :

where [6]:

$$
\tau_{\mathrm{mIt}}=\sqrt{\mathrm{t}^{2}-\overrightarrow{t^{2}}}
$$

$$
J^{1}=\frac{\int_{0}^{\infty} d h(L, x)^{2} d t}{\int_{0}^{\infty} h(t, x) f_{d t}}, j=1,2
$$

Ior each location $x$, a value for $i$ and $\tau_{m}$ s were obtained. Fi, 2 , shows the cumulatve distribution furction (CDF) of RMS delay sprend values. The CDF shows the probability thet $\tau_{\text {rma }}$ is greater than the value given on abseisea. The result is similar to the cthers, all ready contmunicalod $[3,4]$.

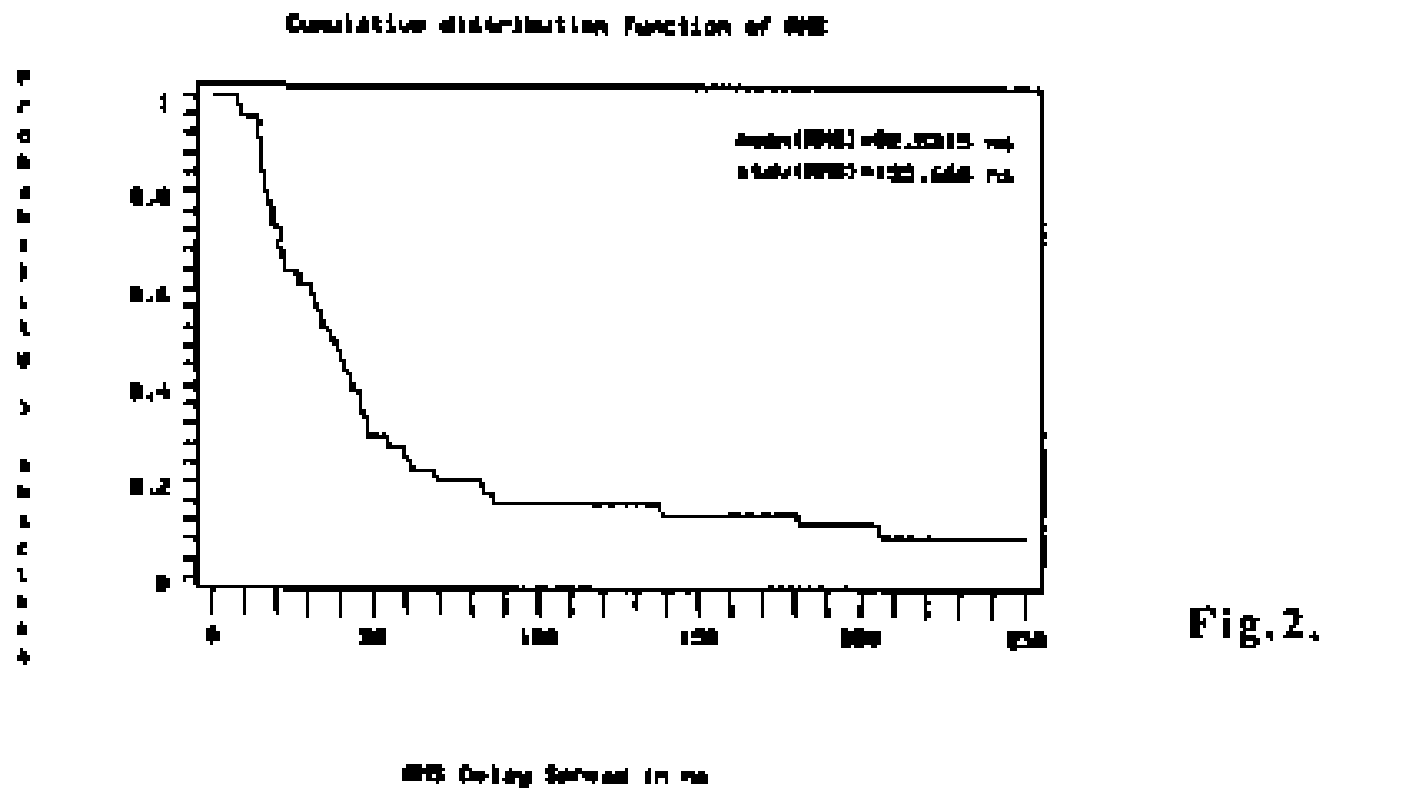

Fig.3. is a scatter plot of the $i$ and $\tau_{\mathrm{m}} \mathrm{m}$ as functions of the distance berweren the transmitting and receiving antennas. The linear regression lines shows thal the both time paratnetes generdly jinerease with $\mathrm{T}$ - $\mathrm{R}$ separation. The correlation coefficient are quite low $\left(0.7\right.$ for $\overline{\mathrm{t}}, 0.52$ for $\tau_{\mathrm{r} / \mathrm{t}}$ ) and the emor is quite itnportant ( $E=61.5 \mathrm{~ns}$ for $\bar{t}$ and $\mathrm{E}=115.3 \mathrm{~ns}$ for $\tau$ ths $)$. The bolh otafties indicate the existance of a location with a very important error the wechole chambet. For this locucion there was do LOS berween the antennas. This abservation suggests to thodify the ajalysis, in order to diseard thls location. In [aet, the aralysts program was irpproved, in order to identify the location with the most important etror, to discard this location and to repen the tegrssive andysts. The results are shown in Table 1 and Table 2 . 

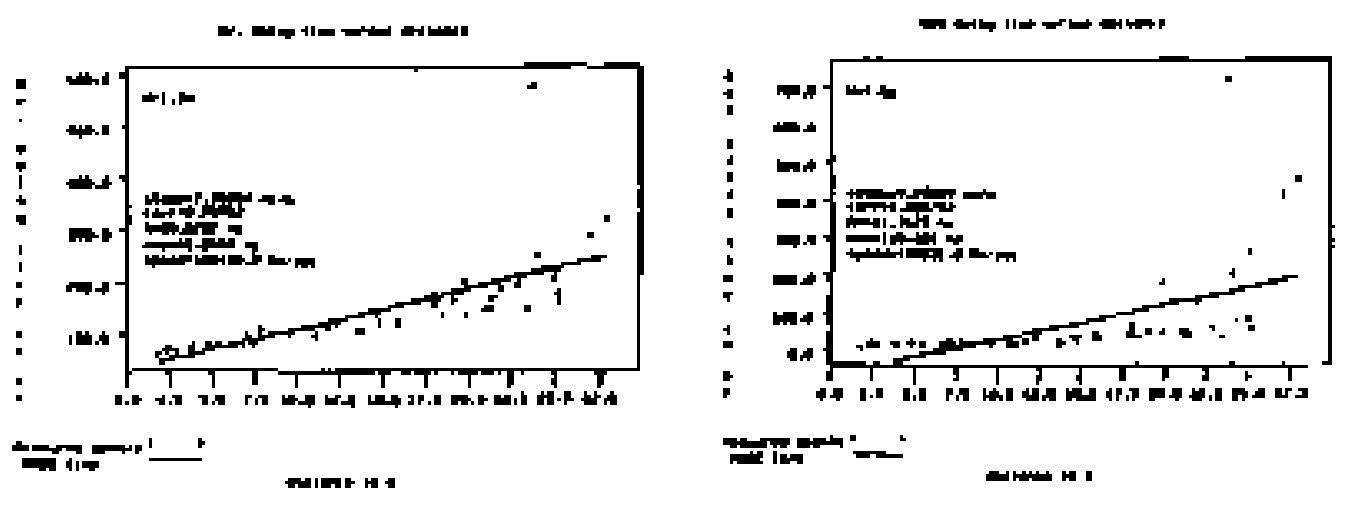

Ftg.3.

Table 1 Tormeters for avenge dely time

\begin{tabular}{|c|c|c|c|c|c|}
\hline \multirow[b]{2}{*}{ Dint } & \multicolumn{5}{|c|}{$\bar{i}$} \\
\hline & cor & $\begin{array}{l}\text { ernor } \\
(\mathrm{ni})\end{array}$ & $\begin{array}{l}\text { slops } \\
(n s / m)\end{array}$ & $\begin{array}{l}\text { intercept } \\
\text { (nd) }\end{array}$ & $\left(x_{1}^{s} \phi^{3} \mathrm{Km} / \mathrm{s}\right)$ \\
\hline all dato & 0.707 & 61.56 & 7,99 & 29.87 & 125 \\
\hline 31 & 0.891 & 26.71 & 6.83 & 39.35 & 146 \\
\hline 31,34 & 0.904 & 22.59 & 6.34 & 44.55 & 157 \\
\hline $31,34,32$ & 0.917 & 19,02 & 5.92 & 48.82 & 168 \\
\hline $31,34,32,30$ & 0.930 & 16.45 & 5.66 & 51.13 & 176 \\
\hline $31,34,32,30,28$ & 0.936 & 15.51 & 5.57 & 51.52 & 179 \\
\hline
\end{tabular}

Table 2 Parameters for RMS deiny spread

\begin{tabular}{|c|c|c|c|c|}
\hline \multirow[b]{2}{*}{ Dath } & \multicolumn{4}{|c|}{ प्राम } \\
\hline & corr & $\begin{array}{l}\text { error } \\
\text { (ns) }\end{array}$ & $\begin{array}{l}\text { glope } \\
\text { (ns/m) }\end{array}$ & $\begin{array}{l}\text { intertept } \\
\text { (ns) }\end{array}$ \\
\hline all data & 0.526 & 1153 & 9.25 & -61.76 \\
\hline 31 & 0.597 & 7.03 & 7.45 & -47.00 \\
\hline 31,34 & 0.582 & 62.27 & 5.90 & -30.60 \\
\hline $31,34,32$ & 0.608 & 42.29 & 4.37 & $-14,87$ \\
\hline $31,34,32,33$ & 0.620 & 33,07 & 3.57 & -7.32 \\
\hline $31,34,32,33,30$ & 0.639 & 26.01 & 2,97 & -2.10 \\
\hline
\end{tabular}


mit:

Using the results presented above, some conclasions can be pointed

1) the elimination of the location placed in the anechoje chamber increases the conrelation coefficients and significanthy decreases the errors beween messued points and MMSE line;

2) the correlation coeffeient generslly increases with decreasing trort

3) the successive effmination of the locations with the grealest errors coincide with increasing values for the average propagation speed. So, this locettions have the longest pathe between antenvits. It is stignificant that the locations are nearly the same for the both parameters. Usiog the plat of the groudfloor of the LCST laboratory (the tesi tirea), it miy be seen that all this locebions art pluced in a eormer of the "Hyperfiequences" chamber, next to the anechoie charbber,

4) for RMS delky apread, even after the elinimition of several locationa, the correlation coeffiefent rests quite singlt. So, the RMS delay time is weakly correluted with T - R separation. It depends on the conctete anthitectue of the building.

\section{CONCLUSION}

We presented the sesults of $0.8-1 \mathrm{GHz}$ mujtipath propagation mensurements performed in the frequency dowain using a nelwork analyzer. For each location, the frequency response of the indoor radio chartitel was measured and the bime-response was computed Then, the average time delay and RMS delay sprest was 250-300 ns. The measured RMS delay spread hes a moan of 82.5 ns and a standard deviation of $135 \mathrm{~ns}$. This large walues are due to the anechine charnber, It may be shown that the elintination of aome locentions decreases the RMS delay spread range at 10 - 70 ns, with lower mean and standard deviation.

\section{REFERENCES}

[1] SALEH, A.M, ant VALEAZUELA, R.A.:"A statistical model for indoor mulbipath propegation", IEEE J.Sel, Areas CommLn., Vol. SAC - 5 , feb. 1987 , pp. $128-137$

[2] HAWBAKER, D.A, and RAPPAPORT, T.S.: "Indoor wideband radiowave propagution measurements at $1.3 \mathrm{GHz}$ and $4.0 \mathrm{GHz}^{m}$, Electron,Left. Vol.26. No.21,oet. 1990, pp. 1800 - 1802

[3] DEVASIRVATHAM, D.M, , ; "Tume delay sprend nteasurentents of wide-band ndio system within a building" ${ }^{2}$ Electron Letr., Vol.20, No.23, nov. 1944 , pp. 950 - 951

[4] DEVASIR VATHAM, D,M.J.: "Time delay spread and gigna: level measunements of $850 \mathrm{MHz}$ radio waves in building etrinontrents", IEEE Trans, AP - 34, No.11, 1986, Fp. 1300 - 1305

[5] HOWARD, S.I, and PAHLAVAN, K.; "Measurement and analytis of the indoor channet in the troxuency donsin", JEEE Trous., 1990, IM - 39. pp. 751 - 755

[6] PAHLAYAN, $K+$ and HOWARD, S.]. "Frequeney donain medsurements of radio indoor ratito channel", Electron.Lett., 1989, 25, pp. $1645=1647$

[7] ZAGHLOUL, K., MORRISON, G., and FATOUCHE, M.: "Frequency response and path loss measurements of the indoor channel", Electron. Let, 1991, 27, (12), pp. $1021-1022$

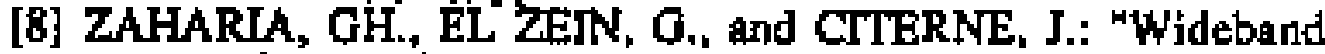
messuremeats and analyeis of propagetion losses within a building", subraitted ot Joint \$ymposia, IEEE-APS Intemat. Symp. Chicago, july, 1992 